Abant Tıp Dergisi

Araştırma Makalesi / Cilt 10 Sayı 1 Yıl 2021
Abant Medical Journal

Research Article / Volume 10 Issue 1 Year 2021

\title{
Coronavirüs Hastalığı 2019 (Covid-19) Olgularının Klinik Özellikleri ve Obstruktif Uyku Apne Sendromu ile İlişkisi: Kesitsel Bir Çalışma
}

\author{
Clinical Characteristics of Coronavirus Disease 2019 (Covid-19) Cases and Relationship with \\ Ostructive Sleep Apnea Syndrome: A Cross-Sectional Study
}

\author{
Selen ILHAN ALP ${ }^{1}$ (iD), Ulugbik KHAYRi ${ }^{2}$ iD, Aykut DEMIRKIRAN ${ }^{3}$ (iD) \\ ${ }^{1}$ Tekirdağ Namık Kemal Üniversitesi, Sağlık Hizmetleri Meslek Yüksekokulu, Tekirdağ, Türkiye \\ ${ }^{2}$ Tekirdağ Devlet Hastanesi Göğüs Hastalıkları Kliniği, Tekirdağ, Türkiye \\ ${ }^{3}$ Tekirdağ Devlet Hastanesi Kardiyoloji Kliniği, Tekirdağ, Türkiye
}

Öz

GiRiş ve AMAÇ: Obstruktif uyku apne sendromu (OUAS) olgularının bağışıklık sisteminin olumsuz etkilendiği ve COVID enfeksiyonunun ağır seyredebileceğine yönelik öngörüler mevcuttur. Bu çalışmada Tekirdağ Devlet Hastanesi'nde COVID-19 tanısı almış olguların uyku kalitesi ve OUAS semptomlarının ve COVID klinik derecesi ile ilişkisinin araştırılması amaçlanmıştır

YÖNTEM ve GEREÇLER: Çalışmamız Coronavirus hastalığı 2019 (COVID-19) salgının ülkemizde ilk yükselişi sırasında 15 Mart 2020- 30 Mayıs 2020 tarihleri arasında Tekirdağ Devlet Hastanesine başvurmuş ve sereolojik testleri pozitif ve klinik olarak tanı konmuş bireylerde yapılmıştır. Tüm olgular Epworth Uykululuk skalası ve Berlin Uyku anketine göre OUAS düşünülen olgularda klinik şiddet ile uyku kalitesi arasındaki ilişki değerlendirildi.

BULGULAR: COVID-19 hastalarında semptomatik olması ve obezite varlığı ile Epworth gündüz uykululuğu arasında istatistiksel olarak anlamlı bir ilişki olduğu tespit edildi $(p<0,05)$. Hastalığın semptomatik ve radyolojik bulguları olanlar ile Berlin risk durumu arasında istatistiksel olarak anlamlı bulunmuştur $(p<0,05)$. Ayrıca hastalığın seyri ile Berlin risk durumu arasında istatistiksel olarak anlamlı bir ilişki vardır $(p<0,05)$. Benzer şekilde obezite, kronik hastalığı olanlar ile Berlin risk durumu arasında da istatistiksel olarak anlamlı bir ilişki bulunmuştur $(p<0,05)$. COVID hastalarında uyku kalitesinin etkilendiği saptandı.

TARTIŞMA ve SONUÇ: Çalışmamızda kronik hastalığı olanlar, obez, horlama ve gündüz uyuklaması olan bireylerde COVID19 enfeksiyonun daha ağır seyrettiğini gösteren bulgular tespit edilmiştir. OUAS akut hastalıkların kötü gidişatı açısından risk faktörü olduğu söylenebilir.

\section{Abstract}

INTRODUCTION: There are predictions that the immune system of obstructive sleep apnea syndrome (OSAS) cases is affected negatively and Coronavirus disease 2019 (COVID-19) may progress to a severe course. In this study, it was aimed to investigate the relationship between sleep quality and OSAS symptoms and clinical degree of COVID in cases diagnosed with COVID-19 in Tekirdağ State Hospital. METHODS: Our study was carried out in individuals who applied to Tekirdağ State Hospital between March 15, 2020 and May 30, 2020 during the first rise of the epidemic COVID-19 in our country, and who had positive serological tests and clinically diagnosed. In all cases, the relationship between clinical severity and sleep quality was evaluated in cases with OSAS according to Epworth Sleepiness Scale and Berlin Sleep Questionnaire.

RESULTS: In COVID-19 cases, a statistically significant relationship was found between being symptomatic and the presence of obesity and Epworth daytime sleepiness $(p<0.05)$. A statistically significant difference was found between those with symptomatic and radiological findings of the disease and the Berlin risk status $(p<0.05)$. In addition, there is a statistically significant relationship between the course of the disease and the Berlin risk status ( $p<0.05$ ). Similarly, a statistically significant relationship was found between obesity, those with chronic diseases and Berlin risk status $(p<0.05)$. It was found that sleep quality was affected in COVID cases.

DISCUSSION and CONCLUSION: In our study, findings showing that COVID-19 infection progressed more severely in individuals with chronic diseases, obese, snoring and daytime sleepiness. It can be said that OSAS is a risk factor for the poor prognosis of acute diseases.

Anahtar Kelimeler: Uyku Bozuklukları, Uyku Apne Sendromu, COVID-19, Uyku Kalitesi

Keywords: Sleep Disorders, Sleep Apne syndrome, COVID19, Sleep Quality

\section{GíRiş}

Koronavirüs 2019 (COVID-19) genelde solunum yollarının ön planda etkilendiği akut, hayatı tehdit edici viral bir enfeksiyondur (1). Oksijen satürasyonun düşmesi hastalık şiddetini ağırlaştırır. COVID-19 enfeksiyonu için risk 
faktörlerini belirleme özellikle hastalığın takip ve tedavisinin yönetilmesi ve bireysel yaklaşımları belirlemeyi kolaylaştırır. Obstruktif uyku apne sendromu (OUAS) horlama, gece nefes kesilmesi, terleme, sabah yorgunluğu, gündüz aşırı uykululuğu semptomları ile tanımlanır (2). Uyku sırasında oksijen satürasyonunun düşmesi ve enflamatuar süreçlerin olması ile klinik tablo ağırlaşır. Özellikle COVID sürecinde birkaç ortak kronik durumlar, özellikle hipertansiyon, diyabet ve obezite risk faktörleri olarak tanımlanmıştır (2) OUAS, obezite, hipertansiyon, diyabet, kardiyovasküler hastalıklara yol açan sık görülen ve hayati tehdit eden bir hastalıktır. Uyku bozuklukları immün sistemi direk etkileyen ve enfeksiyon için zemin hazırlayan ortam sağlamakta ve COVID hastalarında uyku ile ilişkili bozukluklar sık görülmektedir (3-6). Yapılan çalışmalarda OUAS hastalarında immün sistem etkilenmesi gösterilmiştir $(2,7)$. COVID-19 özellikle bağışıklık sistemi zayıf bireylerde, ileri yaşlarda ve erkeklerde ciddi klinik tablolara yol açmaktadır (8). Bu çalışmamızda COVID-19 pandemisi olarak kabul edilen süreçte COVID-19 tedavisi görmüş olgularda klinik seyir özelliklerinin OUAS ile ilişkisinin olup olmadığının tespiti, cinsiyet ve yaşa göre dağılımlarının belirlenmesi amaçlanmıştır.

\section{GEREÇ ve YÖNTEMLER}

Çalışmamız COVID-19 salgınının ülkemizde ilk kez yükseldiği dönemde 15 Mart 2020- 30 Mayıs 2020 tarihleri arasında Tekirdağ Devlet Hastanesine başvurmuş ve sereolojik testleri pozitif ve klinik olarak tanı konarak tedavi almış bireyler ile yapılmıştır. $\mathrm{Bu}$ olguların sosyodemografik özelliklerinin yer aldığı 15 soruluk anket formu ile Berlin Uyku Anketi, Epworth Uykululuk skalası ve Pittsburgh uyku kalitesi ölçekleri internet ortamında gönderilerek, anketlere yanıtları alınarak, değerlendirilme yapılmıştır. Epworth Uykululuk Ölçeği gündüz uyku halini göstermek içi kullanılan bir testtir. Sekiz sorudan oluşur. Her soruya hasta tarafından 0-3 puan vererek doldurulur. Tüm sorularda uykuya dalma olasılığı hiç yoksa 0 , düşük ise 1 , orta ise 2 ve yüksek ise 3 puan alır. Toplam puan 10 ve üzerinde ise gündüz aşırı uyku halinin varlığına işaret eder (9). Berlin anketi OUA toplum taramaları için düzenlenmiş bir ankettir. Toplam 3 kategoride 10 soru bulunmaktadır. Kategori 1 ve $2^{\prime}$ de $\geq 2$ puan ve kategori 3'te $\geq 1$ puan anlamlı kabul edilir. Her kategori kendi içerisinde değerlendirilerek 2 veya daha fazla kategori pozitif çıkarsa OSAS riski yüksek kabul edilir (10). Pitsburgh Uyku Kalitesi Indeksi (PUKi), subjektif uyku kalitesi, uyku latansı, uyku süresi, habitüel uyku etkinliği, uyku bozuklukları, uyku ilacı kullanımı ve gündüz fonksiyonları olmak üzere 7 ana başlıkta sorulan sorular ile uyku kalitesini değerlendiren bir ankettir (11). Hastaların primer olarak klinik takiplerini yapan hekimlerin kayıtlarına göre COVID olguları, ayaktan ve yatarak tedavi görenler olarak sınıflandırılmıştır.

İstatistiksel analizler: i̇statistiksel analizlerde ankete katılan bireylere ilişkin demografik tanımlamalar Frekans ( $n$ ) ve Yüzde (\%) olarak ve ölçeklerde yer alan sorulara ilişkin Ortalama (Ort) ve Standart Sapma (SS) değerleri tablolarda verildi. Verilerin Normal dağılıma uygunluğunun belirlenmesi için Kolmogorov-Smirnov testi uygulandı. İstatistiksel analizlerde IBM SPSS Amos 21 istatistiksel Paket Programı SPSS 21.0 programı kullanıldı. Gruplar arasındaki farkların analizleri için Ki-kare, Fischer's Exact test, t-test kullanıldı. Ortalamalar ortalama \pm standart sapma olarak verildi. Sonuçlardan $p<0.05$ olanlar istatistiksel olarak anlamlı kabul edildi.

\section{BULGULAR}

\section{Sosyodemografik Bulgular:}

Çalışmamızda internet ortamında cevap veren ve çalışma özeliklerini kapsayan toplam 155 olgu dahil edilmiştir. Bu olguların sosyodemografik özellikleri Tablo 1'de gösterilmiştir. Katılımcıların $\% 57,4$ 'ü erkektir. \%69'u hastalığı serviste yatarak atlatmıştır. Araştırmaya katılan hastaların yaş ortalaması 40,4 $\pm 15,67^{\prime}$ dir. Katılımcıların $\% 64,5^{\prime} \mathrm{i}$ 
evli olduklarını, \%70,3'ü sigara kullanmadığını ve $\% 85,8$ 'i alkol kullanmadığını belirtmiştir. Katılımcıların \%37,4'ü kendi evinde, \%35,5'i ise ailesinin evinde kalmakta, \%56,8'i evde eşi ve çocuklarıyla beraber yaşamaktadır. Katılımcıların \%40'ı ilkokul mezunudur. \%45,8'i herhangi bir işte çalışmadığını ifade etmiştir. Katılımcıların $\% 47,7$ 'si asgari ücret düzeyinde gelire sahiptir. Katılımcıların \%63,9' u uyku düzensizliği olduğunu belirtmiştir. Katılımcıların \%80'i yapılan sadece testlerinin pozitif bulunduğunu belirtirken, \%20'si ise semptomlu ve/veya akciğer tomografisi aracılığı ile teşhis konulduğunu ifade etmiştir. Katılımcıların \%72,3'ü bir hastalıklarının olmadığını belirtmiştir. Katılımcıların \%31,6’ü kilolu veya obezite idi (Tablo 1 ).

Uykuya dalma süresi ortalaması $18,93 \pm 17,84$ dakika olarak tespit edilmiştir. Katılımcıların uyku

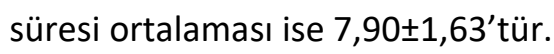

Hastaların OUA varlığı hem Epwort hem de Berlin Uyku ölçeğine göre değerlendirildiğinde Epwort ölçeğinde elde edilen sonuçlara göre katılımcıların \%82,6'sının gündüz uykululuğu yokken, \%17,4'ünde gündüz uykululuğu mevcuttur. Berlin Uyku ölçeği sonucuna göre katılımcıların \%72,3'ünün düşük risk grubunda olduğu, \%27,7'sinin ise yüksek risk grubunda olduğu tespit edilmiştir (Tablo 2).

Hastaların uyku kalitesi PUKi ölçeği kullanılarak değerlendirilmiştir. Katılımcıların PUKi alt boyutlarından ve genel ölçek toplamından aldıkları puanlar minimum, maksimum, ortalama ve standart sapma olarak verilmiştir. Buna göre katılımcıların PUKi 1. Bileşeninden aldıkları puan ortalaması 1,19 $\pm 0,85^{\prime}$ tir. 2. Bileşen puan ortalamaları $2,90 \pm 0,40,3$. Bileşen puan

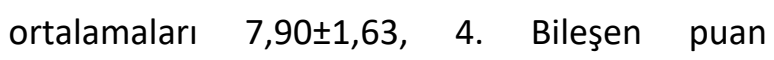
ortalamaları $0,26 \pm 0,60,5$. Bileşen puan ortalamaları $1,1 \pm 0,72$, 6 . Bileşen puan ortalamaları $0,27 \pm 0,75$ ve 7 . Bileşen puan

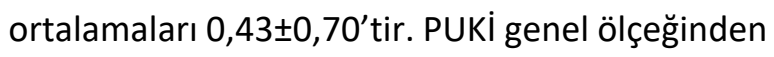
alınan puan ortalaması ise $14,12 \pm 2,48^{\prime}$ dir (Tablo 3).

\section{Klinik Değerlendirme Bulguları:}

Hastalığın klinik seyri, obezite ve kronik hastalık ile gündüz uykululuğu arasındaki ilişki değerlendirildiğinde Epworth gündüz uykululuğu değeri arasında istatistiksel olarak anlamlı bir ilişki olduğu tespit edilmiştir $(p<0,05)$. Tablo 4'te görüleceği üzere, sadece testi pozitif bulunan kişilerin \%86,3'ünün gündüz uykululuğu yokken, $\% 13,7$ 'sinin vardır. Öte yandan semptomlu olan ve/veya akciğer tomografisinde hastalık bulgularına rastlanan bireylerin $\% 32,3$ 'ü gündüz uykululuğuna sahiptir. Hastalığın nasıl atlatıldığı ile Epworth gündüz uykululuğu arasında istatistiksel olarak anlamlı bir ilişki yoktur $(p>0,05)$. Obezite durumu ile epworth gündüz uykululuğu arasında istatistiksel olarak anlamlı bir ilişki tespit edilmiştir $(p<0,05)$. Burada obezite durumu olanların gündüz uykululuk durumlarının daha yüksek olduğu görülmektedir. Kronik hastalık durumu ile Epworth gündüz uykululuğu arasında ise istatistiksel olarak anlamlı bir ilişki tespit edilememiştir ( $p>0,05)$ (Tablo 4).

Yine benzer bir şekilde hastalığın nasıl atlatıldığı, seyri ile obezite ve kronik hastalık varlığı ile OUA Berlin risk durumunun derecesi arasında istatistiksel olarak anlamlı bir ilişki olduğu tespit edilmiştir $(p<0,05)$. Tablo 5' da görüleceği üzere semptomlu olan ve/veya akciğer tomografisi ile hastalık bulguları tespit eden bireylerin \%48,4'ü Berlin risk durumu açısından yüksek riskli grupta yer almaktadır. Hastalığın nasıl atlatıldığı ile Berlin risk durumu arasında istatistiksel olarak anlamlı bir ilişki vardır $(p<0,05)$. Buna göre serviste yatarak atlatanların daha yüksek oranda yüksek risk grubunda yer aldığı tespit edilmiştir. Benzer şekilde obezite ile Berlin risk durumu arasında da istatistiksel olarak anlamlı bir ilişki vardır $(p<0,05)$. Burada obezite durumu olanların Berlin risk durumu açısından daha yüksek oranda yüksek risk grubunda yer aldığı tespit edilmiştir. Son olarak kronik hastalık durumu ile Berlin risk durumu arasında da istatistiksel olarak anlamlı bir ilişki tespit edilmiş olup ( $p<0,05)$, kronik hastalığa sahip olanların Berlin risk durumu açısından daha 
yüksek oranda yüksek risk grubunda yer aldığı tespit edilmiştir.

Hastaların klinik seyri açısından PUKi alt boyutları ve PUKi genel toplamı ile istatistiksel olarak anlamlı bir farklılık olmadığı tespit edilmiştir $(p>0,05)$ (Tablo 6).

Olguların hastalıklarının tespit edilme türüne göre PUKi genel ölçek ve alt boyutları ortalamaları açısından farklılık olup olmadığı incelenmiştir. Buna göre 4. Bileşen, 5. Bileşen, 7. Bileşen ve PUKi genel puanları açısından gruplar arasında istatistiksel olarak anlamlı farklılıklar tespit edilmiştir $(p<0,05)$. Öte yandan, 1. Bileşen, 2. Bileşen, 3. Bileşen ve 6 . Bileşen açısından gruplar arasında istatistiksel olarak anlamlı bir farklılık yoktur $(p>0,05)$. 4.Bileşen olan alışılmış uyku etkinliği incelendiğinde semptomlu olan ve/veya akciğer tomografisiyle hastalık bulguları tespit edilen katılımcıların daha yüksek bir sıra ortalamasına sahip olduğu, bu gruptaki bireylerin alışımış uyku etkinliği açısından daha olumsuz bir durumda olduğu görülmektedir. 5. Bileşen olan uyku bozukluğu incelendiğinde yine semptomlu olan ve/veya akciğer tomografisiyle hastalık bulguları tespit edilen katılımcıların daha yüksek bir sıra ortalamasına sahip olduğu, bu gruptaki katılımcıların daha yüksek düzeyde uyku bozukluğu yaşadığı tespit edilmiştir. 7.Bileşen olan gündüz işlev bozukluğu incelendiğinde benzer şekilde semptomlu olan ve/veya akciğer tomografisiyle hastalık bulguları tespit edilen katılımcıların daha yüksek bir sıra ortalamasına sahip olduğu, bu gruptaki katılımcıların daha yüksek düzeyde gündüz işlev bozukluğu yaşadığı görülmektedir. Son olarak PUKi genel ölçek puanı üzerinden değerlendirme yapıldığında, yine semptomlu olan ve/veya akciğer tomografisiyle hastalık bulguları tespit edilen katılımcıların daha yüksek bir sıra ortalamasına sahip olduğu, bu gruptaki katılımcıların uyku kalitesinin daha düşük olduğu görülmektedir (Tablo 7).

PUKi alt boyutları ve genel ölçek puanı açısından obezite durumuna göre 1. Bileşen, 5. Bileşen, 6 .
Bileşen, 7. Bileşen ve PUKi toplamı istatistiksel olarak anlamlı bir farklılık göstermektedir $(p<0,05)$. Bu bileşenler ve PUKi toplamı incelendiğinde obezite durumu olan bireylerin daha yüksek sıra ortalamalarına sahip oldukları, bu nedenle genel olarak uyku kalitelerinin daha düşük olduğu ifade edilebilir. Diğer bileşenler açısından istatistiksel olarak anlamlı bir farklılık tespit edilememiştir $(p>0,05)$ (Tablo 8).

Hastaların cinsiyet, yaş ve kronik hastalık durumlarına göre Epworth uykululuk, Berlin Uyku anketi değerlendirmelerine göre istatistiksel farklılık tespit edilmemiştir. Cinsiyet dağılımına göre PUKi genel ölçek ve alt boyutları ortalamaları açısından farklııı incelenmiş ve 3 . Bileşen ve PUKi genel ölçek puanları açısından cinsiyete göre istatistiksel olarak anlamlı bir farklılık olduğu tespit edilmiştir $(p<0,05)$. 3.Bileşen olan uyku süresi incelendiğinde kadınların sıra ortalamalarının erkeklere göre daha yüksek olduğu görülmektedir. Ayrıca Genel ölçek puanı açısından da kadınların sıra ortalamalarının daha yüksek olduğu ve erkeklere göre daha düşük uyku kalitesine sahip olduğu tespit edilmiştir. Öte yandan diğer bileşenler cinsiyete göre istatistiksel olarak anlamlı bir fark göstermemektedir ( $p>0,05)$ (Tablo 9).

\section{TARTIŞMA}

Çalışmamızda kullanmış olduğumuz Epwort Uykululuk skalası ve Berlin Uyku Anketi, uyku apne sendromunun polisomnografik inceleme olmadan belirlememek için kullanılan ölçütlerdir. Her iki testin birçok toplumsal ve klinik hastalıkta OUAS belirtilerinin belirlenmesi amacıyla yapılmış çalışmaları mevcuttur $(12,13)$. OUAS tanısı için altın standart olan polisomnografik inceleme olmakla birlikte klinik bulguların ve belirtilerin olması hastalık varlığını araştırmak ve tanı koymak açısından önemlidir.

COVID-19 hastalarında hastane kayıtlarının retrospektif değerlendirilmesi ve risk analizleri şeklinde yapılmış güncel çalışmalarında OUAS sendromunun varlığının hastalık seyrine etkisi 
üzerinde etkisi bildirilmiştir. Çalışmamızın özellikle hastalığın dünyada ilk olarak tanı konduğu ve pandemi olarak kabul edildiği zamanda yapılması önemlidir. Elde ettiğimiz sonuçlarda özellikle hastalık seyrinin obezite ve kronik hastalık ile gündüz uykululuğu arasındaki ilişki değerlendirildiğinde Epworth gündüz uykululuğu değeri arasında istatistiksel olarak anlamlı bir ilişki olduğu tespit edilmiştir. Özellikle hastanede tedavi altına alınan kliniği daha belirgin olan hastalarda bu ilişki anlamlı bulunmuştur. Yine benzer bulgular Belin Uyku anketi sonuçlarında da görülmüştür. Özellikle kronik hastalığı olan, obez hastalarda klinik gidişatın OUAS belirtileri ile ilişkili olduğunu göstermiştir. COVID pandemesinin uyku kalitesini olumsuz yönde etkilediği gösterilmiş olup çalışmamızda da benzer veriler elde edilmiştir (5).

Yapılan çalışmalarda COVID pandemisi sırasında OUAS tanısı konmuş hastaların, ağır semptomatik hastalık geçirme ve hastalığa yakalanma oranları 8 kat daha fazla olduğu izlenmiştir $(12,14)$. Bu durum değişik ülkelerde yaş, cinsiyet, ırk ve sosyoekonomik açıdan farklılık göstermektedir. COVID 19 hastaları arasında OUAS artmış risk ile ilişkilendirilmiştir. OUAS sendromu olan hastaların hastanede yatış ve solunum yetmezliği gelişme riskini yaklaşık 2 kat arttırdığı gösterilmiştir. Diyabetik hastalarda OUAS eşlik etmesi hastalı̆ı̆n seyri üzerinde olumsuz etki gösterdiği belirtilmiştir (14).

Obezite varlığının enfeksiyon gidişatı açısından olumsuz etkisi yine litaretürde çalışılıı̧ ve obezitenin hastalık seyri üzerine etkisi olduğu bildirilmiştir. Özellikle Amerika ve Batı ülkelerinde gözlenen yüksek ölüm oranlarının bu durumlarla ilişkili olabileceği tartışımaktadır (15).

Çalışmamız özellikle COVID-19 hastalığının gidişatının ağır olmasında OUAS belirtilerinin varlığının katkı sunduğunu göstermiştir. Ayrıca OUAS belirtilerinin önceden bilinmesi, hasta eğitiminin ve tedavilerinin yapılması mortalite oranlarını düşüreceğini düşünmekteyiz. Bu çalışmamızın verilerin internet ortamında doldurulması ve sayının az olması çalışmanın zayıf noktalarıdır. Daha büyük sayıda, multisentrik, komorbit faktörlerin araştırılacağı çalışmalara ihtiyaç vardır. Ayrıca hastalığın daha erken tanınması ve tedavisinin yapılmasının mortaliteyi azaltacağı düşünülmektedir $(14,16)$.

Çalışma için Tekirdağ NKÜ klinik araştırmalar etik kurulundan onay alınmıştır (22,06.2020E.28641).

Bilgilendirilmiş Onam: Katılımcılardan yazılı onam alınmıştır.

Çıkar Çatışması: Yazarlar çıkar çatışması beyan etmemişlerdir.

Finansal Destek: Yazarlar finansal destek beyan etmemişlerdir.

\section{KAYNAKLAR}

1. Hoxie World Health Organization. Novel Coronavirus China. https://wwwwhoint/csr/don/12-january-2020novel-coronavirus-china/en/ (access Feb 17, 2020) 2020.

2. Türk Toraks Derneği Obstrüktif Uyku Apne Sendromu Tanı ve Tedavi Uzlaşı Raporu 2012.

3. F Zhang, Z Shang, $H$ Ma, Y Jia, L Sun, X Guo, L Wu, Z. Sun, Y. Zhou, Y. Wang, N. Liu, W. Liu High risk of infection caused posttraumatic stress symptoms in individuals with poor sleep quality: A study on influence of coronavirus disease (COVID-19) in China. MedRxIV. 2020.2 (online). https://doi.org/10.1101/2020.03.22.20034504.

4. Mello MT, Silva A, Guerreiro RC, da-Silva FR, Esteves AM, Poyares D, et al. Sleep and COVID-19: considerations about immunity, pathophysiology, and treatment. Sleep Sci.2020;13(3):199-209

5. Xiao H, Zhang Y, Kong D, Li S, Yang N. Social Capital and Sleep Quality in Individuals Who Self-Isolated for 14 Days During the Coronavirus Disease 2019 (COVID-19) Outbreak in January 2020 in China. Med Sci Monit. 2020 Mar 20;26: e923921.

6. H. Xiao, Y. Zhang, D. Kong, S. Li, N. Yang. The Effects of Social Support on Sleep Quality of Medical Staff Treating Patients with Coronavirus Disease 2019 (COVID-19) in January and February 2020 in China. Med Sci Monit. 2020; 26: e923549-1-e923549-8.

7. Benjafield AV, Ayas NT, Eastwood PR, Heinzer R, Ip MSM, Morrell MJ, Nunez CM, Patel SR, Penzel T, Pépin JL, Peppard PE, Sinha S, Tufik S, Valentine K, Malhotra 
A (2019) Estimation of the global prevalence and burden of obstructive sleep apnoea: a literature-based analysis. Lancet RespirMed. 7(8):687-698.

8. Richardson S, Hirsch JS, NarasimhanM, Crawford JM, McGinn T, Davidson KW, and the Northwell COVID-19 Research Consortium, Barnaby DP, Becker LB, Chelico JD, Cohen SL, Cookingham J, Coppa K, Diefenbach MA, Dominello AJ, Duer- Hefele J, Falzon L, Gitlin J, Hajizadeh N, Harvin TG, Hirschwerk DA, Kim EJ, Kozel ZM, Marrast LM, Mogavero JN, Osorio GA, QiuM, Zanos TP (2020) Presenting Characteristics, comorbidities, and outcomes among 5700 patients hospitalized with COVID-19 in the New York City area. JAMA. 323:20522059. https://doi.org/10.1001/jama.2020.6775.

9. Izci B, Ardic S, Firat $H$, et al. Reliability and validity studies of the Turkish version of the Epworth Sleepiness Scale. Sleep Breath 2008; 12:161-8.

10. Abrishami A, Khajehdehi A, Chung F. A systematic review of screening questionnaires for obstructive sleep apnea. Can J Anaesth 2010; 57:423-38

11. Buysse DJ, Hall ML, Strollo PJ, et al. Relationships between the Pittsburgh Sleep Quality Index (PSQI), Epworth Sleepiness Scale (ESS), and clinical/polysomnographic measures in a community sample. J Clin Sleep Med 2008; 4:563-71.

12. Chiner $E$, Llombart $M$, Valls J, Pastor $E$, Sancho-Chust JN, Andreu AL, Sánchez-de-la-Torre M, Barbé F (2016) Association between obstructive sleep apnea and community-acquired pneumonia. PLoS One. 11(4): e0152749.

https://doi.org/10.1371/journal.pone.0152749.

13. Tufik S, Gozal D, Ishikura IA, Pires GN, Andersen ML (2020) Does obstructive sleep apnea lead to increased risk of COVID-19 infection and severity? J Clin Sleep Med. 16:1425-1426.

14. Maas MB, Kim M, Malkani RG, Abbott SM, Zee PC.
Obstructive Sleep Apnea and Risk of COVID-19 Infection, Hospitalization and Respiratory Failure [published online ahead of print, 2020 Sep 29]. Sleep Breath. 2020;1-3

15. Turan $D$, Tanrıverdi $E$, Çörtük $M$, Yıldııım ZB, Uğur Chousei EG, Çınarka H, Özgul MA, Çetinkaya E. Is Body Mass Index a Risk Factor in the Clinical Course of Patients with Coronavirus Disease 2019 Pneumonia? SCIE. 2020; 31(4): 324-328

16. Nagappa $M$, Liao $P$, Wong J, Auckley D, Ramachandran SK, Memtsoudis S, Mokhlesi B, Chung F (2015) Validation of the STOP-Bang Questionnaire as a Screening tool for obstructive sleep apnea among different populations: a systematic review and metaanalysis. PLoS One. 10(12): e0143697. 
Tablo 1. Hastaların genel sosyodemografik özellikleri

\begin{tabular}{|c|c|c|c|}
\hline & DEĞİŞKENLER & $\mathbf{N}$ & $\%$ \\
\hline \multirow[t]{2}{*}{ Cinsiyet } & Kadın & 66 & 42,6 \\
\hline & Erkek & 89 & 57,4 \\
\hline \multirow[t]{2}{*}{ Hastalığın nasıl atlatıldı $\breve{g}_{1}$} & Serviste yatış & 107 & 69,0 \\
\hline & Ayaktan & 48 & 31,0 \\
\hline \multirow[t]{3}{*}{ Yaşadığ1 yer } & Köy & 9 & 5,8 \\
\hline & İlçe & 79 & 51,0 \\
\hline & Şehir & 67 & 43,2 \\
\hline \multirow[t]{4}{*}{ Medeni durum } & Evli & 100 & 64,5 \\
\hline & Bekâr & 41 & 26,5 \\
\hline & Eşi vefat etmiş & 12 & 7,7 \\
\hline & Boşanmış & 2 & 1,3 \\
\hline \multirow[t]{5}{*}{ Sigara kullanımı } & Yok & 109 & 70,3 \\
\hline & Tek tük & 9 & 5,8 \\
\hline & Birakmış & 14 & 9,0 \\
\hline & Günde 1 paket & 16 & 10,3 \\
\hline & Haftada 1 paket & 7 & 4,5 \\
\hline \multirow[t]{2}{*}{ Uyku düzensizliği } & Var & 99 & 63,9 \\
\hline & Yok & 56 & 36,1 \\
\hline \multirow[t]{2}{*}{ Hastalığın tespit edilmesi } & Sadece testi pozitif & 124 & 80,0 \\
\hline & Test +Semptomlu ve/veya tomografi ile & 31 & 20,0 \\
\hline \multirow[t]{2}{*}{ Hastalık durumu } & Var & 43 & 27,7 \\
\hline & Yok & 112 & 72,3 \\
\hline \multirow[t]{3}{*}{ Obezite } & Evet & 49 & 31,6 \\
\hline & Hayır & 106 & 68,4 \\
\hline & TOPLAM & 155 & 100 \\
\hline
\end{tabular}


Tablo 2. Epworth Gündüz Uykululuğu ve Berlin Uyku Ölçeğine Göre OUAS Risk Oranları

\begin{tabular}{lcrr}
\hline & DEĞIŞKEN & N & \% \\
\hline Epworth Gündüz & Evet & 27 & 17,4 \\
Uykululuğu & Hayır & 128 & 82,6 \\
\cline { 2 - 4 } & & & 27,7 \\
\hline Berlin Risk Durumu & Yüksek risk & 43 & 72,3 \\
\cline { 2 - 4 } & Düşük risk & 112 & 100 \\
\hline & TOPLAM & 155 & \\
\hline
\end{tabular}

Tablo 3. Puki Alt Boyutlari Ve Genel Toplam

\begin{tabular}{lcccc}
\hline DEĞİşKEN & Minimum & Maksimum & Ortalama & Standart Sapma \\
\hline 1.Bileşen &, 00 & 3,00 & 1,19 &, 85 \\
2.Bileşen & 1,00 & 3,00 & 2,90 &, 40 \\
3.Bileşen & 4,00 & 15,00 & 7,90 & 1,63 \\
4.Bileşen &, 00 & 3,00 &, 26 &, 60 \\
5.Bileşen &, 0 & 3,0 & 1,1 &, 72 \\
6.Bileşen &, 00 & 3,00 &, 27 &, 75 \\
7.Bileşen &, 00 & 2,00 &, 43 &, 70 \\
PUKİ TOPLAM & 9,00 & 21,00 & 14,12 & 2,48 \\
\hline
\end{tabular}

Tablo 4. Hastalık seyri ile Epworth gündüz uyuklama arasındaki ilişki.

\begin{tabular}{|c|c|c|c|c|c|c|}
\hline \multicolumn{2}{|c|}{ DEĞİISKENLER } & \multicolumn{5}{|c|}{ Epworth Gündüz Uykululuğu } \\
\hline & & Evet (\%) & Hayır (\%) & $\mathrm{X}^{2}$ & sd & $\begin{array}{l}\text { Anlamlılık } \\
\text { (p) }\end{array}$ \\
\hline \multirow{2}{*}{$\begin{array}{l}\text { Hastalı̆̆ın } \\
\text { Tespiti }\end{array}$} & Sadece testi pozitif & $17(13,7)$ & $107(86,3)$ & 5,931 & 1 & 0,015 \\
\hline & $\begin{array}{l}\text { Semptomlu ve/veya } \\
\text { Akciğer tomografisi }\end{array}$ & $10(32,3)$ & $21(67,7)$ & & & \\
\hline \multirow{2}{*}{$\begin{array}{l}\text { Hastalı̆̆ } 1 \\
\text { Seyri }\end{array}$} & Serviste Yatış & $19(17,8)$ & $88(82,2)$ & 0,027 & 1 & 0,869 \\
\hline & Ayaktan & $8(16,7)$ & $40(83,3)$ & & & \\
\hline \multirow[t]{2}{*}{ Obezite } & Evet & $15(30,6)$ & $34(69,4)$ & 8,669 & 1 & 0,003 \\
\hline & Hayır & $12(11,3)$ & $94(88,7)$ & & & \\
\hline \multirow{2}{*}{$\begin{array}{l}\text { Kronik } \\
\text { Hastalık }\end{array}$} & Var & $12(27,9)$ & $31(72,1)$ & 4,550 & 1 & 0,056 \\
\hline & Yok & $15(13,4)$ & $97(86,6)$ & & & \\
\hline
\end{tabular}


Tablo 5. Hastalığın tespiti ve nasıl atlatıldığı, obezite ve kronik hastalık ile Berlin Uyku anketine göre OUAS risk durumu arasındaki ilişkiler

\begin{tabular}{|c|c|c|c|c|c|c|}
\hline \multicolumn{2}{|c|}{ DEĞİSSKENLER } & \multicolumn{5}{|c|}{ Berlin Risk Durumu } \\
\hline & & $\begin{array}{l}\text { Yüksek } \\
\text { Risk (\%) }\end{array}$ & $\begin{array}{l}\text { Düşük } \\
\text { Risk (\%) }\end{array}$ & $\mathbf{X}^{2}$ & sd & $\begin{array}{l}\text { Anlamlılık } \\
\text { (p) }\end{array}$ \\
\hline \multirow{2}{*}{$\begin{array}{l}\text { Hastalı̆ğn } \\
\text { Tespiti }\end{array}$} & Sadece testi pozitif & $28(22,6)$ & $96(77,4)$ & 8,239 & 1 & 0,004 \\
\hline & $\begin{array}{l}\text { Semptomlu ve/veya } \\
\text { Akciğer tomografisi }\end{array}$ & $15(48,4)$ & $16(51,6)$ & & & \\
\hline \multirow{2}{*}{$\begin{array}{l}\text { Hastalığg } \\
\text { Seyri }\end{array}$} & Serviste Yatış & $37(34,6)$ & $70(65,4)$ & 8,058 & 1 & 0,005 \\
\hline & Ayaktan & $6(12,5)$ & $42(87,5)$ & & & \\
\hline \multirow[t]{2}{*}{ Obezite } & Evet & $36(73,5)$ & $13(26,5)$ & 74,740 & 1 & 0,000 \\
\hline & Hayır & $7(6,6)$ & $99(93,4)$ & & & \\
\hline \multirow{2}{*}{$\begin{array}{l}\text { Kronik } \\
\text { Hastalık }\end{array}$} & Var & $26(60,5)$ & $17(39,5)$ & 31,789 & 1 & 0,000 \\
\hline & Yok & $17(15,2)$ & $95(84,8)$ & & & \\
\hline
\end{tabular}

Tablo 6. Hastalığın klinik seyrine göre PUKi ortalamaları açısından farklar

\section{HASTALIĞIN KLİNIK SEYRİ}

\section{Sira Ortalamaları}

\begin{tabular}{lccc} 
PUKİ BiLEŞENLERİ & Serviste Yatıs & Ayaktan & Anlamlılık (p) \\
\hline 1.BİLEŞEN & 80,57 & 72,27 & 0,260 \\
2.BİLEŞEN & 77,67 & 78,73 & 0,724 \\
3.BİLEŞEN & 76,73 & 80,83 & 0,592 \\
4.BİLEŞEN & 76,61 & 81,09 & 0,414 \\
5.BİLEŞEN & 80,32 & 72,83 & 0,278 \\
6.BİLEŞEN & 80,09 & 73,34 & 0,154 \\
7.BILLEŞEN & 80,21 & 73,08 & 0,262 \\
PUKİ TOPLAM & 80,65 & 72,08 & 0,268 \\
\hline
\end{tabular}


Tablo 7. Hastalığın seyrine göre PUKi ortalamaları açısından farklar

\section{HASTALIĞIN SEYRI}

\section{Sira Ortalamaları}

PUKİ BİLEŞENLERİ Testi Pozitif $\begin{gathered}\text { Semptomlu ve/veya Akciğer } \\ \text { tomografisi }\end{gathered} \quad$ Anlamlılık (p)

\begin{tabular}{lccc}
\hline 1.BİLEŞEN & 76,70 & 83,21 & 0,445 \\
2.BİLEŞEN & 78,27 & 76,94 & 0,700 \\
3.BİLEŞEN & 78,98 & 74,06 & 0,579 \\
4.BİLEŞEN & 74,34 & 92,63 & 0,004 \\
5.BİLEŞEN & 71,85 & 102,58 & 0,000 \\
6.BİLEŞEN & 77,50 & 80,02 & 0,645 \\
7.BİLEŞEN & 72,61 & 99,55 & 0,000 \\
PUKİ TOPLAM & 72,86 & 98,55 & 0,004 \\
\hline
\end{tabular}

Tablo 8. Obezite durumuna göre PUKi ortalamaları açısından farklar

\section{OBEZITE DURUMU}

Sira Ortalamaları

\begin{tabular}{lccc} 
PUKİ BILESŞENLERİ & Evet & Hayır & Anlamlılı (p) \\
\hline 1.BİLEŞEN & 99,13 & 68,23 & 0,000 \\
2.BİLEŞEN & 74,15 & 79,78 & 0,058 \\
3.BİLEŞEN & 80,82 & 76,70 & 0,589 \\
4.BİLEŞEN & 76,45 & 78,72 & 0,678 \\
5.BİLEŞEN & 90,76 & 72,10 & 0,007 \\
6.BİLEŞEN & 86,06 & 74,27 & 0,012 \\
7.BİLEŞEN & 90,33 & 72,30 & 0,004 \\
PUKİ TOPLAM & 97,13 & 69,16 & 0,000 \\
\hline
\end{tabular}


Tablo 9. Cinsiyete göre PUKi ortalamaları açısından farklar

\section{CINSIYYT}

Sira Ortalamaları

\begin{tabular}{lccc} 
PUKİ BILEŞENLERİ & Kadın & Erkek & Anlamlılı (p) \\
\hline 1.BİLEŞEN & 80,45 & 76,18 & 0,535 \\
2.BİLEŞEN & 79,68 & 76,75 & 0,295 \\
3.BİLEŞEN & 88,59 & 70,15 & 0,010 \\
4.BİLEŞEN & 82,75 & 75,01 & 0,171 \\
5.BİLEŞEN & 80,85 & 75,89 & 0,442 \\
6.BILEŞEN & 80,83 & 75,90 & 0,266 \\
7.BILEŞEN & 74,36 & 80,70 & 0,286 \\
PUKİ TOPLAM & 88,51 & 70,21 & 0,011 \\
\hline
\end{tabular}

